\title{
PENINGKATAN KUALITAS PEMBELAJARAN MELALUI SUPERVISI AKADEMIK DENGAN TEKNIK KUNJUNGAN KELAS
}

\author{
Diah Nanda Permatasari
}

\author{
Email: diahnandapermatasari1999@gmail.com
}

\begin{abstract}
ABSTRAK
Dalam era teknologi dan globalisasi yang semakin berkembang saat ini, peranan kepala sekolah dalam meningkatkan mutu pendidikan melalui supervisi sangat berperan penting. Kepala sekolah merupakan faktor penggerak bagi sumber daya sekolah terutama guru dan peserta didik. Salah satu tindakan yang harus dilakukan adalah membimbing dan membina guru dalam kegiatan supervisi akademik, yang merupakan bantuan profesional kepada guru untuk meningkatkan kemampuan profesional guru dalam proses pembelajaran. Supervisi akademik yang paling mudahdan sering dilakukan oleh Kepala Sekolah adalah supervisi akademik dengan teknik kunjungan kelas, yaitu Kepala Sekolah sebagai supervisor mengadakan kunjungan kelas pada saat guru mengajar di kelas. Melalui teknik supervisi yang dilakukan oleh kepala sekolah dengan melakukan kunjungan langsung terhadap guru dan peserta didik ini diharapkan mampu berpengaruh terhadap peningkatan mutu dan kualitas pemebalajarn yang dilakukan oleh guru maupun peserta didik dalam pendidikan sehingga menghasilkan lulusan terbaik dan mampu bersaing dengan dunia terlebih dengan era teknologi dan globalisasi seperti sekarang ini. Peningkatan mutu melalui supervisi ini akan dibahas pada artikel "Peningkatan Kualitas Pembelajaran Melalui Supervisi Akademik dengan Teknik Kunjungan Kelas”.
\end{abstract}

Kata kunci: Kualitas pembelajaran, supervisi akademik, kunjungan kelas

\section{LATAR BELAKANG}

Secara umum pendidikan nasional bertujuan untuk mngembangkan setiap potensi yang ada pada setiap peserta didik agar menjadi manusia yang beriman dan bertaqwa kepada Tuhan Yang Maha Esa, berakhlak mulia, sehat, berilmu, cakap, kreatif, mandiri, dan menjadi warga negara yang demokratis serta bertanggung jawab. Berdasarkan tujuan pendidikan tersebut supervisi sangat diperlukan dalam rangka meningkatkan mutu dan kualitas pendidikan. Melalui supervisi diharapkan tujuan 
pendidikan dapat tercapai dengan baik dan mampu menghasilkan mutu dan kualitas pendidikan yang baik juga.

Disamping itu Permendikbud nomor 22 tahun 2016 menyatakan bahwa proses pembelajaran pada satuan pendidikan diselenggarakan secara interaktif, inspiratif, menyenangkan, menantang, memotivasi peserta didik untuk berpartisipasi aktif, serta memberikan ruang yang cukup bagi prakarsa, kreativitas, dan kemandirian sesuai dengan bakat, minat, dan perkembangan fisik serta psikologis peserta didik. Oleh sebab itu, untuk mewujudkan tujuan tersebut di atas maka peranan Kepala Sekolah dalam mengelola sekolah merupakan hal yang mutlak dalam era industrialisasi, teknologi, dan globalisasi yang berkembang dewasa ini. Kepala Sekolah merupakan motor penggerak bagi sumber daya sekolah terutama guru dan peserta didik. Salah satu upaya untuk meningkatkan kualitas sumber daya manusia ialah melalui proses pembelajaran di sekolah, di mana guru merupakan komponen sumber daya manusia yang harus dibina dan dikembangkan secara terus menerus, sistematis dan sesuai dengan aturan-aturan yang ada di lingkungan pendidikan.

Pada era teknologi dan globalisasi saat ini tidak dapat dipungkiri dunia pendidikan harus mampu bersaing dengan perkembangan zaman. Dimana pada saat sekarang ini dunia pendidikan harus mampu menghasilkan lulusan yang bermutu dan berkualitas. Melalui supervisi diharapkan mutu dan kualitas pendidikan dapat meningkat sesuai dengan perkembangan zaman. Namun seperti yang kita lihat dilapangan, saat sekarang ini kondisi supervisi pendidikan di sekolah masih jauh dari kata baik. dimana masih banyak sekolah-sekolah yang belum melaksanakan supervisi dengan baik, sehingga secara tidak langsung hal tersbut berdampak pada tingkat kualitas dan lulusan dari peserta didik di sekolah tersebut. Untuk itu melalui analisis artikel ini akan dibahas menganai teknik-teknik dan cara dlam meningkatkan supervisi pembelajaran melalui teknik kunjungan secara langsung. Teknik ini diharapkan mampu meningkan mutu dan kulaitas pendidikan nantinya.

Berdasarkan uraian diatas, menurut kadarwati (Kadarwati, 2016)permasalahan dalam tulisan ini adalah (1) bagaiamana melakukan supervisi akademik melalui teknik kunjungan kelas? (2) Bagaiman cara meningkatkan pemebelajaran melalui supervisi akademik dengan teknik kunjungan kelas? Tujuan tulisan ini adalah untuk mengatahui bagaimana melakukan supervisi akademik melalui teknik kunjungan kelas dan dapat mengetahui cara meningkatkan pembelajaran melalui supervisi akaemik dengan teknik kunjungan kelas.

\section{PEMBAHASAN}

Menurut Sabandi (Sabandi, 2013) menyebutkan bahwa perkembangan supervisi pendidikan seiring dengan perkembanngan ilmu pengetahuan teknologi, social dan eonomi serta budaya masyarakat. Perkembangan supervisi pada era saat ini lebih menekankan pada upaya guru untuk mengembangkan kualitas pembelajarannya melalui pengembangan profesionalan berkelanjutan. Sehubungan dengan 
perkembangan pengetahuan dan teknologi terutama pada era globalisasi saat sekarang ini terjadi perkembangan yang pesat terhadap supervisor dengan jumlah kemampuan yang sangat terbatas.

Menurut Priansa dan Somad (2014:106) bahwa Kepala Sekolah perlu memiliki keterampilan konseptual, interpersonal dan teknikal terkait dengan supervisi akademik. Kegiatan supervisi akademik yang dilaksanakan bukan hanya untuk penilaian kinerja guru dalam mengelola proses pembelajaran di kelas, melainkan juga untuk membantu dalam meningkatkan kemampuan profesionalismenya. Salah satu tindakan yang harus dilakukan adalah membimbing dan membina guru dalam kegiatan supervisi akademik, yang merupakan bantuan profesional kepada guru untuk meningkatkan kemampuan profesional guru dalam proses pembelajaran.

Menurut Kadarwati (2016) guru sebagai ujung tombak dalam proses peningkatan kualitas pendidikan, secara internal harus memacu diri dalam meningkatkan keprofesionalannya. Kepala sekolha sebagai pemimpin dalam lingkungan sekolah harus mampu bertanggungjawab dalam meningktakan profesionalisme guru dalam meningktkan proses pembelajaran. Pada umumnya, kegiatan supervisi akademik yang paling mudahdan sering dilakukan oleh Kepala Sekolah adalah supervisi akademik dengan teknik kunjungan kelas, yaitu Kepala Sekolah sebagai supervisor mengadakan kunjungan kelas pada saat guru mengajar di kelas. Selain itu, supervisi kunjungan kelas ini dapat dipergunakan untuk mensupervisi semua guru yang ada di sekolah, baik untuk guru yang baru diangkat, guru pindahan dari sekolah lain, maupun guru senior yang sudah lama mengajar dan mempunyai banyak pengalaman mengajar. Melalui supervisi dengan teknik kunjungan kelas ini didarapkan mampu meningktkan profesionalsme dan kemapuan guru dalam membentuk proses pembelajaran yang kreatif dan baik sehingga dapat meningkatkan prestasi siswa.

Proses pembelajaran adalah inti dari proses atau kegiatan pendidikan yang dapat berpengaruh terhadap pencapaian tujuan pendidkan untuk menghasilkan lulusan terbaik dan sesuai denga tujuan pendidikan nasional. Melalui analisis artikel peningkatan kualitas pembelajaran melalui supervisi akademik dengan teknik kunjuangn langsung ini dapat dilakukan oleh kepala sekolah selaku pemimpin sekolah. Supervisi dengan teknik kunjungan kelas bertujuan untuk memperoleh data mengenai keadaan sebenarnya selama guru melakukan pembelajaran di kelas. Selain itu, teknik kunjungan kelas dapat berfungsi sebagai alat untuk mendorong guru agar mau dan mampu meningkatkan proses pembelajaran di kelas sehingga motivasi dan hasil belajar peserta didik dapat meningkat menjadi lebih baik. peningktan kualitas pembelajaran melalui supervisi akademik dengan teknik kunjungan dapat dilakukan oleh seorang supervisor dengan bebarapa cara, yaitu:

a. Kunjungan kelas tanpa diberitahu terlebih dahulu

Cara dpat dilakukan oleh seorang kepal sekolah atau seorang supervisor dengan cara langsung berkunjung ke kelas tempat guru yang sedang malakulah proses pembelajaran tanpa ada pemberitahuan terlebih 
dahulu kepada guru. Hali ini dilakukan agar guru dapat menyiapkan pemebalajaran dengan sebaik mungkin akapan pun dan dalam situasi apapun.

b. Kunjungan kelas dengan diberitahu terlebih dahulu

Cara ini dilakukan dengan memberitahu kepada guru terlebih dahulu sebelum melakukan supervisi terhadap guru. Hal ini dilakukan agar guru dapat meyiapkan proses pembelajaran dengan lebih matang dan maksimal.

c. Kunjungan Kelas atau Undangan Guru

Cara ini dilakukan dengan cara guru memberitahu supervisor agar dapat melakukan supervisi dengan melakukan diskusi antara guru dan supervisor dalam usaha meningktkan proses pemebajaran yang baik di dalam kelas.

\section{PENUTUP \\ Kesimpulan}

Berdasarkan uraian diatas ini disimpulkan bahwa kualitas pemeblajaran dapat ditingkatkan melalui supervisi akademik dengan teknik kunjungan kelas dilakukan oleh kepala sekolah atau supervisor dengan beberapa cara yaitu:

a. Kunjungan Kelas tanpa diberitahu terlebih dahulu

b. Kunjungan Kelas dengan dibertahu terlebih dahulu

c. Kunjungan Kelas atau undangna guru

\section{Saran}

Berdasarkan uraian di atas supervisi seharusnya ada pada setiap sekolah dan supervisor diharapkan pembaca dapat mengimplementasikan dalam kehidupan seharihari sehingga hal ini akan berdampak pada peningktan kualitas pembelajaran oleh guru dan dapat berpengaruh terhadap meningkatnya kualitas dan mutu peserta didik.

\section{Referensi}

Kadarwati, A. (2016). No Title peningkatan kualitas pembelajaran melalui supervisi akademik dengan teknik kunjungan kelas. Pedagogi, 1(1), 18. Retrieved from file:///C:/Users/ACER/Downloads/1034-1910-1-SM.pdf

Sabandi, A. (2013). No Title supervisi pendidikan untuk pengembangan profesionalitas guru berkelanjutan. Pedagogi, XIII(2), 14. Retrieved from http://ejournal.unp.ac.id/index.php/pedagogi/article/view/4275 